\title{
Derivation and Culture of Epiblast Stem Cell (EpiSC) Lines
}

\author{
Peter Rugg-Gunn
}

This protocol describes the derivation and culture of epiblast stem cells (EpiSCs) from early postimplantation epiblasts. EpiSCs can be maintained in an undifferentiated state and retain the ability to generate tissues from all three germ layers in vitro and to form teratomas in vivo. However, they seem unable to form chimeras. Whether this is due to differences in developmental status or a cellular incompatibility (e.g., cell adhesion) between EpiSCs and the host inner cell mass (ICM) is currently unclear. Other differences between mouse embryonic stem (ES) cells and EpiSCs also exist, including gene expression profiles and different growth factor requirements for self-renewal. Thus, EpiSCs provide an important in vitro model for studying the establishment and maintenance of pluripotency in postimplantation epiblast tissues.

It is essential that you consult the appropriate Material Safety Data Sheets and your institution's Environmental Health and Safety Office for proper handling of equipment and hazardous material used in this protocol.

RECIPES: Please see the end of this protocol for recipes indicated by $<R>$. Additional recipes can be found online at http://cshprotocols.cshlp.org/site/recipes.

Activin A stock solution $(10 \mu \mathrm{g} / \mathrm{mL})($ ActA; R\&D Systems 338-AC-005) $<\mathrm{R}>$

BSA fraction $\mathrm{V}$ solution in PBS $(0.1 \%, \mathrm{w} / \mathrm{v})<\mathrm{R}>$

$\mathrm{CDM}+\mathrm{FGF} 2+$ ActA medium $<\mathrm{R}>$

Cell dissociation buffer (Invitrogen 13150-016)

Supplement with $3 \mathrm{mg} / \mathrm{mL}$ BSA to prevent embryo sticking. Filter-sterilize.

Chemically defined medium $(\mathrm{CDM})<\mathrm{R}>$

Collagenase type IV $(1 \mathrm{mg} / \mathrm{mL})<\mathrm{R}>$

Early postimplantation embryos (5.5-6.5 dpc [days postcoitum])

Embryo-handling medium (e.g., FHM, Millipore MR-024)

EpiSC medium $<\mathrm{R}>$

EpiSC + FGF2 medium $<$ R $>$

FGF2 stock solution $(10 \mu \mathrm{g} / \mathrm{mL})(\mathrm{R} \& \mathrm{D}$ Systems $233-\mathrm{FB})<\mathrm{R}>$

Fibronectin $(10 \mathrm{mg} / \mathrm{mL})$ (Chemicon FC010)

Flushing and handling medium (FHM), $\mathrm{Ca}^{2+} / \mathrm{Mg}^{2+}$ free

Obtain commercially by special order from embryo culture media supply company.

From the Manipulating the Mouse Embryo collection, edited by Richard Behringer, Marina Gertsenstein, Kristina Vintersten Nagy, and Andras Nagy.

(C) 2017 Cold Spring Harbor Laboratory Press

Cite this protocol as Cold Spring Harb Protoc; doi:10.1101/pdb.prot093971 


\section{Equipment}

Freezing medium for feeder cell culture $(2 \times)<\mathrm{R}>$

Freezing medium for feeder-free culture $(1 \times)<\mathrm{R}>$

Gelatin $(0.1 \%, w / v$, in water, autoclaved) (Swine Skin type II, Sigma-Aldrich G2500)

MEF feeder layer plates (see Protocol: Preparing Mouse Embryo Fibroblasts [Nagy et al. 2006a],

Protocol: Preparing Feeder Cell Layers from STO or Mouse Embryo Fibroblast (MEF) Cells:

Treatment with Mitomycin C [Nagy et al. 2006b], and Protocol: Preparing Feeder Cell Layers from

STO or Mouse Embryo Fibroblast (MEF) Cells: Treatment with $\gamma$-Irradiation [Nagy et al. 2006c])

Pancreatin/trypsin solution $<\mathrm{R}>$

Phosphate-buffered saline (PBS) $<\mathrm{R}>$

Prepare PBS without added $\mathrm{Ca}^{2+}$ and $\mathrm{Mg}^{2+}$. Supplement with $3 \mathrm{mg} / \mathrm{mL}$ BSA to prevent embryo sticking, and then filter-sterilize.

Biosafety cabinet

Embryo-handling pipette (e.g., a finely drawn Pasteur pipette, i.d. $=\sim 100 \mu \mathrm{m}$, attached to an aspirator mouthpiece)

Forceps

Glass scalpels

Fuse the central portion of a glass capillary (o.d. of $1 \mathrm{~mm}$, i.d. of $0.75 \mathrm{~mm}$ ) over a flame, and generate a tapered cutting surface using an electrode puller. For more details, see Downs (2006).

Incubator, humidified, $37^{\circ} \mathrm{C} ; 5 \% \mathrm{CO}_{2}, 95 \%$ air

Microscopes, inverted and stereomicroscope

Needles (30 gauge)

Non-tissue-culture-treated dishes (e.g., $35 \mathrm{~mm}$ )

Pipettes

Pipettors, automatic (P20 and P200)

Tissue-culture dishes (various sizes, including 24-well plates)

1. Derive the EpiSC cell lines from early postimplantation embryos, using either feeder cells or feeder-free conditions.

\section{For Derivation on MEF Feeders}

i. The day before isolating the embryos, prepare gelatin-coated 24-well tissue-culture plates with MEFs at $4 \times 10^{4}$ cells $/ \mathrm{cm}^{2}$.

MEFs derived from 13.5-dpc embryos work best (see Protocol: Preparing Mouse Embryo Fibroblasts [Nagy et al. 2006a], Protocol: Preparing Feeder Cell Layers from STO or Mouse Embryo Fibroblast (MEF) Cells: Treatment with Mitomycin C [Nagy et al. 2006b], and Protocol: Preparing Feeder Cell Layers from STO or Mouse Embryo Fibroblast (MEF) Cells: Treatment with $\gamma$-Irradiation [Nagy et al. 2006c]).

Days 1-2

ii. In the morning of isolating the embryos, replace the medium with EpiSC + FGF2 medium $(500 \mu \mathrm{L} /$ well $)$.

iii. Collect 5.5-6.5 dpc embryos under sterile conditions in FHM, and remove Reichert's membrane using sharp forceps or 30-gauge needles. 
iv. Using a 30-gauge needle or glass scalpel, cut the embryo near the boundary of the embryonic and extra-embryonic regions. Transfer the embryonic fragment (with overlying endoderm) to a drop of ice-cold pancreatin/trypsin and incubate for $5-8 \mathrm{~min}$ at $4^{\circ} \mathrm{C}$. Return the fragment to FHM and allow it to rest for $5 \mathrm{~min}$.

v. Using the finely drawn glass pipette, carefully draw the embryonic fragment into the pipette (cut end first). The epiblast should peel away from the visceral endoderm and enter the pipette.

vi. Transfer each epiblast to an individual well of the 24-well plate containing EpiSC + FGF2 medium and culture for $24 \mathrm{~h}$ at $37^{\circ} \mathrm{C}$ and $5 \% \mathrm{CO}_{2}$ (Fig. 1A).

\section{Days 3-4}

vii. Change the medium after $48 \mathrm{~h}$.

The epiblast outgrowth is ready for passage on Days 3-4 (see Fig. 1B).

viii. Using a glass pipette or 30-gauge needle, cut the colony into four to six equally sized pieces, and transfer the pieces to a fresh well of MEF feeders. Leave behind the extra-embryonic cells that are present in the colony because of poor initial isolation (Fig. 1C,D).

\section{For Derivation in Feeder-Free Conditions}

i. The day before isolating the embryos, coat 24 -well culture dishes with fibronectin. To each well, add $500 \mu \mathrm{L}$ of PBS and $5 \mu \mathrm{L}$ of fibronectin, swirl to coat, and incubate at $37^{\circ} \mathrm{C}$. Use the plate after $1 \mathrm{~h}$ and within $24 \mathrm{~h}$. Just before use, remove the solution, wash once with PBS, and add CDM + FGF2 + ActA.
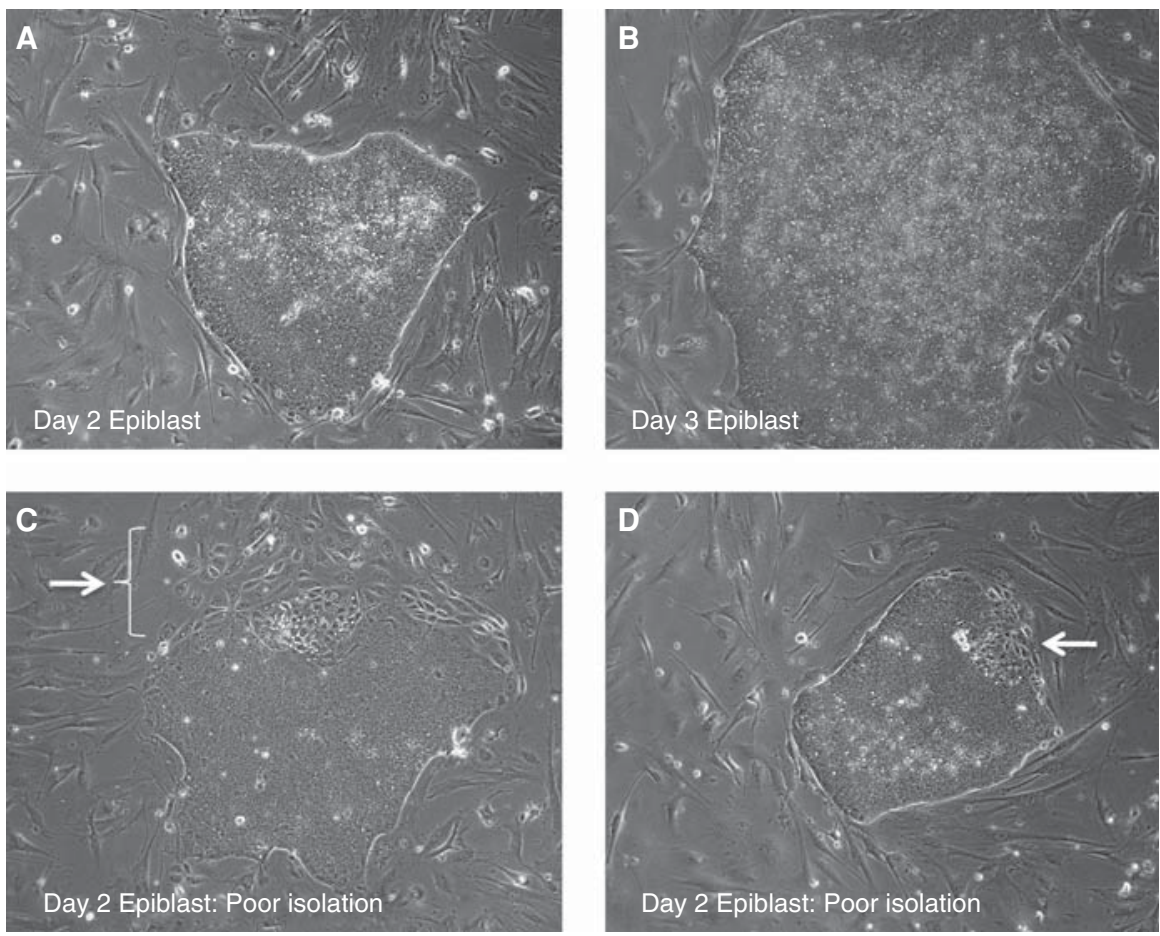

FIGURE 1. Derivation of epiblast stem cells on MEFs. (A) Typical epiblast colony after $2 \mathrm{~d}$ of culture on fibroblast feeders. $(B)$ The same colony after one additional day of culture. $(C, D)$ Examples of epiblast colonies where extraembryonic tissues were not completely removed before plating (indicated by arrows). (Reprinted with permission from Chenoweth and Tesar 2010, (C) Springer Science + Business Media.) 
Day 1

ii. Replace the fibronectin with CDM + FGF2 + ActA (500 $\mu \mathrm{L} /$ well) in the morning of isolating the embryos.

iii. Collect 5.5-6.5 dpc embryos under sterile conditions in FHM, and remove Reichert's membrane using sharp forceps or 30-gauge needles.

iv. Wash the embryos in PBS, $\mathrm{Ca}^{2+} / \mathrm{Mg}^{2+}$-free, containing $3 \mathrm{mg} / \mathrm{mL}$ BSA, and incubate in cell dissociation buffer for $15-20 \mathrm{~min}$ at $4^{\circ} \mathrm{C}$. Transfer the embryos to a 35-mm dish containing ice-cold FHM, $\mathrm{Ca}^{2+} / \mathrm{Mg}^{2+}$-free.

v. While holding the embryo down on the dish with one needle, make small tears near the boundary of the embryonic and extra-embryonic regions using the tip of another needle. As the tear opens up, the visceral endoderm will become easier to reflect and dissect off the epiblast (the endoderm usually comes off as a single sheet of cells). Sever the epiblast from the extra-embryonic ectoderm.

vi. Transfer each epiblast to an individual well of the 24 -well culture dish containing CDM + $\mathrm{FGF} 2+\mathrm{ActA}$, and incubate at $37^{\circ} \mathrm{C}$ and $5 \% \mathrm{CO}_{2}$.

Days 2-5

vii. Change the medium after $24 \mathrm{~h}$ and repeat daily.

The EpiSC colonies should be large and ready for passage by Days 6-10.

Days 6-10

viii. Add collagenase type IV ( $0.5 \mathrm{~mL} /$ well of a 24 -well plate $)$ and incubate for $1-2 \mathrm{~min}$ at room temperature. Carefully remove collagenase and add $0.5 \mathrm{~mL}$ of CDM. Using a P20 pipette, pick EpiSC colonies and transfer cell clumps to a new well containing CDM + FGF2 + ActA.

2. From now on, change the medium daily (using CDM + FGF2 + ActA for cells grown with feeder cells or using EpiSC + FGF2 for feeder-free conditions). Passage the cells using collagenase type IV. Distribute the cells at a 1:1 or 1:2 ratio for the first few passages.

Culturing EpiSC Cells

3. Culture EpiSCs with or without MEF feeder cells.

\section{To Culture Cells on MEF Feeder Cells}

i. Prepare gelatin-coated tissue-culture dishes with MEF feeders at a density of $4 \times 10^{4}$ cells/ $\mathrm{cm}^{2}$. MEFs derived from 13.5-dpc embryos work best (see Protocol: Preparing Mouse Embryo Fibroblasts [Nagy et al. 2006a], Protocol: Preparing Feeder Cell Layers from STO or Mouse Embryo Fibroblast (MEF) Cells: Treatment with Mitomycin C [Nagy et al. 2006b], and Protocol: Preparing Feeder Cell Layers from STO or Mouse Embryo Fibroblast (MEF) Cells: Treatment with $\gamma$-Irradiation [Nagy et al. 2006c]).

ii. Culture EpiSCs on MEF feeders in EpiSC + FGF2 medium in a standard tissue-culture incubator $\left(37^{\circ} \mathrm{C}, 5 \% \mathrm{CO}_{2}\right)$. Change the medium every day and passage the cells (1:4-1:6) every $2-3 \mathrm{~d}$ or when the culture has reached $\sim 50 \%$ confluency. The optimum density of EpiSCs is variable and should be determined for each line.

iii. Add collagenase type IV (e.g., $1 \mathrm{~mL} /$ well of a six-well plate) and incubate for 8-12 min at $37^{\circ} \mathrm{C}$. Add $1 \mathrm{~mL}$ of EpiSC medium to each well, gently dislodge the colonies by pipetting with a $5-\mathrm{mL}$ pipette, and transfer the cells to a $15-\mathrm{mL}$ conical tube. Collect the colonies by centrifugation at $200 \mathrm{~g}$ for $15 \mathrm{sec}$. 
P. Rugg-Gunn

iv. Remove the supernatant, and gently resuspend the colony pellet in $5 \mathrm{~mL}$ of EpiSC medium. Collect the colonies by centrifugation at $200 \mathrm{~g}$ for $15 \mathrm{sec}$, and repeat the wash and centrifugation once more (for a total of three times).

v. Resuspend the colonies in $100 \mu \mathrm{L}$ of EpiSC medium, and transfer them to one well of a 96well round-bottom plate. Gently break up the colonies into small clumps using a P200 pipette. Transfer the clumps onto fresh MEF feeders in EpiSC + FGF2 medium.

\section{To Culture Cells in Feeder-Free Conditions}

i. Prepare the plates by coating using one of the following options:

- For treatment with fibronectin. Add $500 \mu \mathrm{L}$ of PBS and $5 \mu \mathrm{L}$ of fibronectin to each well of a 12 -well plate. Swirl to coat and incubate at $37^{\circ} \mathrm{C}$. Use the plate after $1 \mathrm{~h}$ and within $24 \mathrm{~h}$. Just before use, remove the solution, wash once with PBS, and add CDM + FGF2 + ActA.

- For treatment with gelatin followed by serum. Coat each well with gelatin and replace it with MEF media (containing at least 10\% fetal bovine serum [FBS]) (Protocol: Preparing Mouse Embryo Fibroblasts [Nagy et al. 2006a]). Incubate overnight at $37^{\circ} \mathrm{C}$ and use within 1 wk. Just before use, remove the media, wash once with PBS, and add CDM + FGF2 + ActA.

ii. Culture the EpiSCs on fibronectin- or serum-coated dishes in CDM + FGF2 + ActA medium in a standard tissue-culture incubator $\left(37^{\circ} \mathrm{C}, 5 \% \mathrm{CO}_{2}\right)$. Change the medium every day and passage the cells $(1: 4-1: 6)$ every $2-3 \mathrm{~d}$ or when the culture has reached $\sim 50 \%$ confluency. The optimum density of EpiSCs is variable and should be determined for each line.

iii. Add collagenase type IV (e.g., $0.5 \mathrm{~mL} /$ well of a 12 -well plate) and incubate for 5-8 min at room temperature. Gently dislodge the cells from the plate using the tip of a $5-\mathrm{mL}$ pipette or cell scraper, and transfer the cells to a $15-\mathrm{mL}$ conical tube.

iv. Add $5 \mathrm{~mL}$ of CDM, collect the cells by centrifugation at $200 \mathrm{~g}$ for $3 \mathrm{~min}$, and wash once more with CDM. The cells should not need much trituration — the ideal size clump should contain $\sim 500-1000$ cells $(\sim 300 \mu \mathrm{M})$.

v. Resuspend the cells in CDM + FGF2 + ActA and transfer to fresh fibronectin-coated or serum-coated dishes.

\section{Cryopreservation of EpiSCs}

4. Freeze and thaw the EpiSCs using procedures similar to those described for ES cells (Protocol: Freezing and Thawing of Embryonic Stem (ES) Cells Using Cryovials [Nagy et al. 2006d]). Prepare freshly prepared freezing medium and keep on ice before adding to the cells.

i. To freeze EpiSCs cultured on MEFs. Add $2 \times$ freezing medium for feeder cell culture to the cell suspension in equal volume.

ii. To freeze EpiSCs cultured in feeder-free conditions. Add $1 \times$ freezing medium directly to the cell pellet obtained from the feeder-free culture.

Although the isolation of epiblast tissue from the early postimplantation embryo requires careful dissection, once the tissue has been obtained, the efficiency of establishing an EpiSC line is very high (close to 100\%). The procedures above are based on publications by Brons et al. (2007), Tesar et al. (2007), Guo et al. (2009), and Greber et al. (2010). For more details, see Chenoweth and Tesar (2010).

Alternatively, stable EpiSC lines may also be derived from the preimplantation embryo (Najm et al. 2011). Although the derivation efficiency appears to be lower (reported to be 26\%), this 


\section{RECIPES}

approach may be technically easier for many laboratories, and you are referred to Najm et al. (2011) for further details. Irrespective of their method of derivation, EpiSCs require FGF2 and Activin A to maintain an undifferentiated state and can be propagated on MEF feeders or in feeder-free conditions.

Stable EpiSC-like cell lines can also be obtained from in vitro differentiation of ES cells. The protocol involves transferring ES cells into EpiSC culture conditions (e.g., Activin and FGF supplementation) and propagating the resulting EpiSC-like colonies. For more details, see Guo et al. (2009), Greber et al. (2010), and Zhang et al. (2010).

Activin A Stock Solution $(10 \mu \mathrm{g} / \mathrm{mL})$

\begin{tabular}{ll} 
Reagent & Amount \\
\hline Recombinant Activin A (ActA; R\&D Systems 338-AC-005) & $5 \mu \mathrm{g}$ \\
BSA fraction V solution in PBS $(0.1 \%$, w/v $)<$ R $>$ & $0.5 \mathrm{~mL}$
\end{tabular}

Resuspend lyophilized Activin A in its vial, mix well, aliquot $50 \mu \mathrm{L}$, and freeze at $-80^{\circ} \mathrm{C}$. Thaw each aliquot as needed and store it at $4^{\circ} \mathrm{C}$. Do not refreeze.

BSA Fraction V Solution in PBS $(0.1 \%, w / v)$

\begin{tabular}{lc} 
Reagent & Amount \\
\hline BSA fraction V (Sigma-Aldrich A3311 or A1470) & $10 \mathrm{mg}$ \\
Phosphate-buffered saline (PBS) without $\mathrm{Ca}^{2+} / \mathrm{Mg}^{2+}<\mathrm{R}>$ & $10 \mathrm{~mL}$ \\
Resuspend BSA in PBS. Filter through a $0.45-\mu \mathrm{m}$ filter, aliquot, and store at $-80^{\circ} \mathrm{C}$.
\end{tabular}

$\mathrm{Ca}^{2+} / \mathrm{Mg}^{2+}$-Free Tyrode Ringer's Saline

$\mathrm{NaCl}, 8.0 \mathrm{~g}$

$\mathrm{KCl}, 0.3 \mathrm{~g}$

$\mathrm{NaH}_{2} \mathrm{PO}_{4} \cdot 5 \mathrm{H}_{2} \mathrm{O}, 0.093 \mathrm{~g}$

$\mathrm{KH}_{2} \mathrm{PO}_{4}, 0.025 \mathrm{~g}$

$\mathrm{NaHCO}_{3}, 1.0 \mathrm{~g}$

Glucose, $2.0 \mathrm{~g}$

Dissolve in 1 liter of $\mathrm{H}_{2} \mathrm{O}$. Adjust $\mathrm{pH}$ to 7.6-7.7.

$C D M+F G F 2+A c t A$ Medium

\begin{tabular}{lccc} 
Reagent & Stock concentration & Final concentration & Amount \\
\hline FGF2 stock solution $<\mathrm{R}>$ & $10 \mu \mathrm{g} / \mathrm{mL}$ & $12 \mathrm{ng} / \mathrm{mL}$ & $12 \mu \mathrm{L}$ \\
Activin A stock solution $<\mathrm{R}>$ & $10 \mu \mathrm{g} / \mathrm{mL}$ & $20 \mathrm{ng} / \mathrm{mL}$ & $20 \mu \mathrm{L}$ \\
Chemically defined medium & & & $10 \mathrm{~mL}$
\end{tabular}

$$
(\mathrm{CDM})<\mathrm{R}>
$$

Store at $4^{\circ} \mathrm{C}$ and use within $1 \mathrm{wk}$. 
Chemically Defined Medium (CDM)

Reagent

Amount Final concentration

F-12 Nutrient Mixture (Ham) with GlutaMAX (Invitrogen $250 \mathrm{~mL}$ 31765-035)

Iscove's modified Dulbecco's medium (IMDM) with $250 \mathrm{~mL}$ GlutaMAX (Invitrogen 31980-030)

BSA $^{\mathrm{a}}$ fraction V (e.g., Equitech-Bio, Inc., BAC62 or Sigma- $\quad 2.5 \mathrm{~g} \quad 5 \mathrm{mg} / \mathrm{mL}$ Aldrich A1470)

Thioglycerol (11.5 M stock; Sigma-Aldrich M7522)

Insulin $(10 \mathrm{mg} / \mathrm{mL}$ stock; Roche 11376497001$)$

Transferrin (30 mg/mL stock; Roche 10652202001)

Chemically defined lipid concentrate (100× stock;

Invitrogen 11905-031)

$\begin{array}{rr}20 \mu \mathrm{L} & 450 \mu \mathrm{M} \\ 350 \mu \mathrm{L} & 7 \mu \mathrm{g} / \mathrm{mL} \\ 250 \mu \mathrm{L} & 15 \mu \mathrm{g} / \mathrm{mL} \\ 5 \mathrm{~mL} & 1 \times\end{array}$

Store the medium (final $500 \mathrm{~mL}$ ) at $4^{\circ} \mathrm{C}$ and use within $1 \mathrm{mo}$.

${ }^{a}$ BSA may need to be batch-tested.

\section{Collagenase Type IV $(1 \mathrm{mg} / \mathrm{mL})$}

Dissolve $0.5 \mathrm{~g}$ of collagenase type IV (Invitrogen 17104-019) in $500 \mathrm{~mL}$ of EpiSC medium $\left\langle\mathrm{R}>\right.$. Filter, aliquot in $10 \mathrm{~mL}$, and freeze at $-80^{\circ} \mathrm{C}$. Thaw each aliquot as needed and store it at $4^{\circ} \mathrm{C}$ (do not refreeze).

EpiSC + FGF2 Medium

\begin{tabular}{lccr} 
Reagent & Stock concentration & Final concentration & Amount \\
\hline FGF2 stock solution $<\mathrm{R}>$ & $10 \mu \mathrm{g} / \mathrm{mL}$ & $5 \mathrm{ng} / \mathrm{mL}$ & $5 \mu \mathrm{L}$ \\
EpiSC medium $<\mathrm{R}>$ & & $10 \mathrm{~mL}$
\end{tabular}

Store at $4^{\circ} \mathrm{C}$ and use within $1 \mathrm{wk}$.

EpiSC Medium

Reagent

Amount Final concentration

KnockOut D-MEM (Invitrogen 10829-018)

$385 \mathrm{~mL}$

KnockOut Serum Replacement (Invitrogen 10828-028) $\quad 100 \mathrm{~mL} \quad 20 \%$

Nonessential amino acids (10 mM stock; Invitogen $\quad 5 \mathrm{~mL} \quad 0.1 \mathrm{mM}$

11140-050)

$\beta$-Mercaptoethanol (10 mu stock $)^{\mathrm{a}}$

GlutaMAX (200 mM stock; Invitrogen 35050-061)

$5 \mathrm{~mL} \quad 0.1 \mathrm{~mm}$

$5 \mathrm{~mL} \quad 2 \mathrm{~mm}$

Store the medium (final volume $500 \mathrm{~mL}$ ) at $4^{\circ} \mathrm{C}$ and use within $1 \mathrm{mo}$.

${ }^{\mathrm{a}} \beta$-Mercaptoethanol $10 \mathrm{~mm}$ stock is prepared from $14.3 \mathrm{~m}$ stock (Sigma-Aldrich M7522) by adding $7 \mu \mathrm{L}$ to $10 \mathrm{~mL}$ of PBS.

FGF2 Stock Solution $(10 \mu \mathrm{g} / \mathrm{mL})$

Reagent Amount

Recombinant fibroblast growth factor-2 (FGF2; R\&D Systems $\quad 25 \mu \mathrm{g}$ 233-FB-025)

BSA fraction V solution in PBS $(0.1 \%, \mathrm{w} / \mathrm{v})<\mathrm{R}>\quad 2.5 \mathrm{~mL}$

Resuspend lyophilized FGF2 in BSA/PBS, mix well, aliquot $50 \mu \mathrm{L}$, and freeze at $-80^{\circ} \mathrm{C}$.

Thaw each aliquot as needed and store it at $4^{\circ} \mathrm{C}$. Do not refreeze the thawed aliquot. 
Freezing Medium for Feeder Cell Culture (2x)

Reagent

Fetal bovine serum (FBS)

DMSO

KnockOut DMEM

Prepare fresh for each use and keep on ice.

Freezing Medium for Feeder-Free Culture (1X)

Reagent

Final concentration

DMSO

KnockOut Serum Replacement (KSR) (Invitrogen)

$10 \%$

$90 \%$

Prepare fresh for each use and keep on ice.

\section{Pancreatin/Trypsin Solution}

Reagent g/20 mL Final concentration

Pancreatin

Trypsin

Polyvinylpyrrolidone (optional)

0.50

$2.5 \%$

0.10

$0.5 \%$

0.10

$0.5 \%$

Make in $\mathrm{Ca}^{2+} / \mathrm{Mg}^{2+}$-free Tyrode Ringer's saline $<\mathrm{R}>$.

The suspension will be difficult to filter-sterilize through a $0.45-\mu \mathrm{m}$ Millipore filter without low-speed centrifugation or prefiltering through a Whatman No. 1 filter. Store sterile in small aliquots at $-20^{\circ} \mathrm{C}$. Modified from Levak-Svajger et al. (1969).

Phosphate-Buffered Saline (PBS)

\begin{tabular}{|c|c|c|c|c|}
\hline Reagent & $\begin{array}{l}\text { Amount to add } \\
\text { (for } 1 \times \text { solution) }\end{array}$ & $\begin{array}{c}\text { Final } \\
\text { concentration } \\
(1 \times)\end{array}$ & $\begin{array}{l}\text { Amount to add } \\
(\text { for } 10 \times \text { stock })\end{array}$ & $\begin{array}{c}\text { Final } \\
\text { concentration } \\
(10 \times)\end{array}$ \\
\hline $\mathrm{NaCl}$ & $8 \mathrm{~g}$ & $137 \mathrm{~mm}$ & $80 \mathrm{~g}$ & $1.37 \mathrm{M}$ \\
\hline $\mathrm{KCl}$ & $0.2 \mathrm{~g}$ & $2.7 \mathrm{~mm}$ & $2 \mathrm{~g}$ & $27 \mathrm{~mm}$ \\
\hline $\mathrm{Na}_{2} \mathrm{HPO}_{4}$ & $1.44 \mathrm{~g}$ & $10 \mathrm{~mm}$ & $14.4 \mathrm{~g}$ & $100 \mathrm{~mm}$ \\
\hline $\mathrm{KH}_{2} \mathrm{PO}_{4}$ & $0.24 \mathrm{~g}$ & $1.8 \mathrm{mM}$ & $2.4 \mathrm{~g}$ & $18 \mathrm{mM}$ \\
\hline
\end{tabular}

If necessary, $\mathrm{PBS}$ may be supplemented with the following:
$\mathrm{CaCl}_{2} \cdot 2 \mathrm{H}_{2} \mathrm{O}$
$0.133 \mathrm{~g}$
$1 \mathrm{~mm}$
$1.33 \mathrm{~g}$
$10 \mathrm{~mm}$
$\mathrm{MgCl}_{2} \cdot 6 \mathrm{H}_{2} \mathrm{O}$
$0.10 \mathrm{~g}$
$0.5 \mathrm{~mm}$
$1.0 \mathrm{~g}$
$5 \mathrm{mM}$

PBS can be made as a $1 \times$ solution or as a $10 \times$ stock. To prepare $1 \mathrm{~L}$ of either $1 \times$ or $10 \times \mathrm{PBS}$, dissolve the reagents listed above in $800 \mathrm{~mL}$ of $\mathrm{H}_{2} \mathrm{O}$. Adjust the $\mathrm{pH}$ to 7.4 (or 7.2, if required) with $\mathrm{HCl}$, and then add $\mathrm{H}_{2} \mathrm{O}$ to $1 \mathrm{~L}$. Dispense the solution into aliquots and sterilize them by autoclaving for $20 \mathrm{~min}$ at $15 \mathrm{psi}\left(1.05 \mathrm{~kg} / \mathrm{cm}^{2}\right)$ on liquid cycle or by filter sterilization. Store PBS at room temperature.

\section{ACKNOWLEDGMENTS}

I.G.M. Brons at the University of Cambridge and P.J. Tesar at Case Western Reserve University shared protocols, comments, and photographs. 


\section{P. Rugg-Gunn}

\section{REFERENCES}

Brons IG, Smithers LE, Trotter MW, Rugg-Gunn P, Sun B, Chuva de Sousa Lopes SM, Howlett SK, Clarkson A, Ahrlund-Richter L, Pedersen RA, Vallier L. 2007. Derivation of pluripotent epiblast stem cells from mammalian embryos. Nature 448: 191-195.

Chenoweth JG, Tesar PJ. 2010. Isolation and maintenance of mouse epiblast stem cells. Methods Mol Biol 636: 25-44.

Downs KM. 2006. In vitro methods for studying vascularization of the murine allantois and allantoic union with the chorion. Methods $\mathrm{Mol}$ Med 121: 241-272.

Greber B, Wu G, Bernemann C, Joo JY, Han DW, Ko K, Tapia N, Sabour D, Sterneckert J, Tesar P, Scholer HR. 2010. Conserved and divergent roles of FGF signaling in mouse epiblast stem cells and human embryonic stem cells. Cell Stem Cell 6: 215-226.

Guo G, Yang J, Nichols J, Hall JS, Eyres I, Mansfield W, Smith A. 2009. Klf4 reverts developmentally programmed restriction of ground state pluripotency. Development 136: 1063-1069.

Levak-Svajger B, Svajger A, Skreb N. 1969. Separation of germ layers in presomite rat embryos. Experientia 25: 1311-1312.

Nagy A, Gertsenstein M, Vintersten K, Behringer R. 2006a. Preparing mouse embryo fibroblasts. Cold Spring Harb Protoc doi: 10.1101/pdb.prot4398.
Nagy A, Gertsenstein M, Vintersten K, Behringer R. 2006b. Preparing feeder cell layers from STO or mouse embryo fibroblast (MEF) cells: Treatment with mitomycin C. Cold Spring Harb Protoc doi: 10.1101/pdb .prot4399.

Nagy A, Gertsenstein M, Vintersten K, Behringer R. 2006c. Preparing feeder cell layers from STO or mouse embryo fibroblast (MEF) cells: Treatment with $\gamma$-irradiation. Cold Spring Harb Protoc doi: 10.1101/pdb .prot4400.

Nagy A, Gertsenstein M, Vintersten K, Behringer R. 2006d. Freezing and thawing of embryonic stem (ES) cells using cryovials. Cold Spring Harb Protoc doi: 10.1101/pdb.prot4402.

Najm FJ, Chenoweth JG, Anderson PD, Nadeau JH, Redline RW, McKay $\mathrm{RD}$, Tesar PJ. 2011. Isolation of epiblast stem cells from preimplantation mouse embryos. Cell Stem Cell 8: 318-325.

Tesar PJ, Chenoweth JG, Brook FA, Davies TJ, Evans EP, Mack DL, Gardner RL, McKay RD. 2007. New cell lines from mouse epiblast share defining features with human embryonic stem cells. Nature 448: 196-199.

Zhang K, Li L, Huang C, Shen C, Tan F, Xia C, Liu P, Rossant J, Jing N. 2010. Distinct functions of BMP4 during different stages of mouse ES cell neural commitment. Development 137: 2095-2105. 


\section{Derivation and Culture of Epiblast Stem Cell (EpiSC) Lines}

Peter Rugg-Gunn

Cold Spring Harb Protoc; doi: 10.1101/pdb.prot093971

\begin{tabular}{|c|c|}
\hline $\begin{array}{r}\text { Email Alerting } \\
\text { Service }\end{array}$ & Receive free email alerts when new articles cite this article - click here. \\
\hline $\begin{array}{l}\text { Subject } \\
\text { Categories }\end{array}$ & $\begin{array}{l}\text { Browse articles on similar topics from Cold Spring Harbor Protocols. } \\
\text { Cell Culture ( } 301 \text { articles) } \\
\text { Embryonic Stem Cells ( } 55 \text { articles) } \\
\text { Mouse (437 articles) } \\
\text { Stem Cells ( } 46 \text { articles) } \\
\text { Stem Cells, general (70 articles) }\end{array}$ \\
\hline
\end{tabular}

